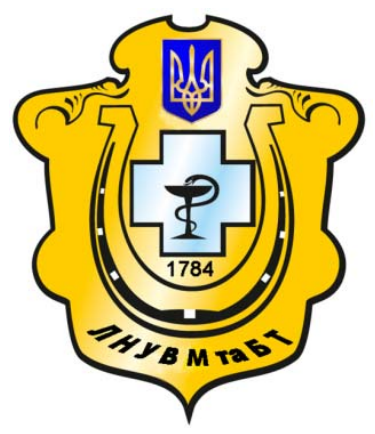

Науковий вісник Львівського національного університету ветеринарної медицини та біотехнологій імені С.3. Гжицького

Scientific Messenger of Lviv National University of Veterinary Medicine and Biotechnologies named after S.Z. Gzhytskyj

doi:10.15421/nvlvet7130

ISSN 2413-5550 print

ISSN 2518-1327 online

$\underline{\text { http://nvlvet.com.ua/ }}$

УДК 619:612.017:636.087.7:635.5

\title{
Особливості гематологічного і білкового профілю та стану неспецифічної резистентності організму птиці при застосуванні пробіотика та нанокобальту
}

\author{
Я.І. Турко, В.О. Ушкалов \\ turko07@ukr.net \\ Львівський національний університет ветеринарної медицини та біотехнологій імені С.3. Гюицького, \\ вул. Пекарська 50, м. Львів, 79010, Україна
}

\begin{abstract}
Одержані результати щзодо стану імунної систем у сукупності з даними динаміки кількості еритроцитів $і$ загального гемоглобіну, змінами у протеїнограмі переконливо свідчать про адаптогенний вплив пробіотику та наночасток Кобальту у дозі 0,08 мг/кг маси тіла на стан неспецифічної резистентності та білкового обміну в організмі дослідної птиці.

Проте аліментарне хронічне потрапляння пробіотику разом з наночастками Кобальту у дозі 0,80 мг/кг маси тіла на пізніх строках досліджень призводило до таких змін у протеїнограмі, що є характерними ознаками порушення білоксинтетичної функиії печінки (за гіпоальбумінемією) та розвитку імуносупресії (за підвищенням рівня серомукоїдів).

За підсумком результатів хронічного токсикологічного експерименту на курях-несучках можна стверджувати про нешкідлиість дії саме пробіотику та пробіотику разом із добавкою Кобальту у вигляді солі та наночасток у дозі 0,08 мг/кг маси тіла, щуо дозволяс вважсати ї̈ дійсно як біотичну.

Адаптогенний ефект препаратів пробіотику та добавки наночасток Кобальту у дозі 0,08 мг/кг маси тіла при аліментарному надходженні до організму курей полягає у посиленні імунних реакцій поряд з відновленням показників еритропоезу та білкового обміну.

Ключові слова: наночастки Кобальту, пробіотик, кров, серомукоїди, циикулюючі імунні комплекси, білки, гемоглобін, еритрочити, лейкоцити, кури.
\end{abstract}

\section{Особенности гематологического и белкового профиля и состояния неспецифической резистентности организма птицы при применении пробиотиками и нанокобальта}

\author{
Я.И. Турко, В.А. Ушкалов \\ turko07@ukr.net
}

\begin{abstract}
Львовский национальный университет ветеринарной медицины и биотехнологий имени С.3. Гжицкого, ул. Пекарская, 50, г. Львов, 79010, Украина
\end{abstract}

\begin{abstract}
Полученные результаты о состоянии иммунной систем в совокупности с данными динамики количества эритроцитов и общего гемоглобина, изменениями в протеинограма убедительно свидетельствуют о адаптогенное воздействие пробиотика и наночастии кобальта в дозе 0,08 мг/кг массы тела в состояние неспецифической резистентности и белкового обмена в организме исследовательской птииь .

Однако алиментарное хроническое попадания пробиотика вместе с наночастицами кобальта в дозе 0,80 мг/кг массы тела на поздних сроках исследований приводило к таким изменениям в протеинограма, что является характерным признакам нарушения билоксинтетичнои функиии печени (по гипоальбуминемией) и развития иммуносупрессии (за повымением уровня серомукоидов).

По итогам результатов хронического токсикологического эксперимента на курах-несушкам можно утверждать о безвредности действия именно пробиотика и пробиотика вместе с добавкой кобальта в виде соли и наночастии в дозе 0,08 мг/кг массы тела, что позволяет считать ее действительно как биотическую.
\end{abstract}

\section{Citation:}

Turko, Ya., Ushkalov, V. (2016). Features of hematological and protein profiles and state of nonspecificresistance ofpoultryin applying probiotics and nanocobalt. Scientific Messenger LNUVMBT named after S.Z. Gzhytskyj, 18, 3(71), 134-138. 
Адаптогенный эффект препаратов пробиотика и добавки наночастии кобальта в дозе 0,08 мг/кг массы тела при алиментарном поступлении в организм кур заключается в усилении иммунных реакций вместе с восстановлением показателей эритропоэза и белкового обмена.

Ключевые слова: наночастиць кобальта, пробиотик, кровь, серомукоиды, циикулируюшие иммуннье комплексы, белки, гемоглобин, эритроциты, лейкоцитыь, курыл.

\title{
Features of hematological and protein profiles and state of nonspecificre- sistance ofpoultryin applying probiotics and nanocobalt
}

\author{
Ya. Turko, V. Ushkalov \\ turko07@ukr.net \\ Lviv national university of veterinary medicine and biotechnologies named after S. Gzhytskyj,
Pekarska Str., 50, Lviv, 79010, Ukraine
}

The obtained results on the state of the immune system in conjunction with these dynamics oferythrocyte number and total hemoglobin, changes in protein gramme convincingly testify adaptogenic effect of probiotics and cobalt nanoparticles at a dose of $0.08 \mathrm{mg} / \mathrm{kg}$ of body weight on the state of nonspecific resistance and protein metabolism in the body of the research poultry.

However alimentary chronic entering of probiotic togetherwith cobalt nanoparticles at a dose of $0.80 \mathrm{mg} / \mathrm{kg}$ at the late terms of research leads to such changes in protein grammewhich are typical signs of protein synthetic liver function (with hypoalbuminemia) and the development of immunosuppression (for increased levels of seromucoid).

According to results of chronic toxicological experiment on laying hensis possible to assert about no harmful actions of probiotics and probiotic along with the addition of cobalt in the form of salts and nanoparticles at a dose of $0.08 \mathrm{mg} / \mathrm{kg}$ of body weight, which makes it really as biotic.

Adaptogenic effect of probiotic preparations and additives of cobalt nanoparticles at a dose of $0.08 \mathrm{mg} / \mathrm{kg}$ of body weight at alimentary earnings to hens body consists in strengthening of immune reactions along with the restoration parameters of erythropoiesis and protein exchange.

Key words: cobalt nanoparticles, probiotics, blood, seromucoid, circulating immune complexes, proteins, hemoglobin, red blood cells, white blood cells, chickens.

\section{Ветуп}

Препарати, в яких присутні наночастинки металів, протидіють патогенній мікрофлорі без порушення генома спадковості, цілеспрямовано регулюються процеси метаболізму поживних речовин і сприяють продуктивності тварин за рахунок підвищення засвоюваності кормів. Метали у вигляді наночастинок, поряд 3 високими бактерицидними властивості, мають істотно меншу токсичність, у порівнянні з солями металів, і не накопичуються в організмі людини тварин (Jefanov, 2011).

За останні роки проведено дослідження з використанням композиційних препаратів із сполук біогенних елементів, наночастинок, іонних форм для профілактики порушень обміну речовин, хвороб травної, дихальної, сечової, серцево-судинної систем, хвороб системи крові, хвороб шкіри. Використання біогенних елементів у композиціях і в різних формах дозволило підвищити їх терапевтичну ефективність при застосуванні ентерально і парентерально, у вигляді аерозолів, місцево, розширити можливості їх цільового використання (Skybab et al., 2009; Jakymchuk et al., 2009; Cvilihovs'kyj et al., 2010; Bereza et al., 2010).

Останнім часом у нашій країні і за кордоном також збільшився інтерес до використання пробіотичних препаратів у птахівництві. У багатьох випадках їх застосування дозволяє вирішити декілька завдань: підвищити ефективність використання поживних речовин, продуктивність птиці; пригнічувати ріст умовно-патогенної і патогенної мікрофлори кишечника, стимулювати імунітет; сприяти зростанню економічних результатів виробництва; забезпечити еко- логічну безпеку продукції (Polishhuk and Bulavkina, 2010; Besulin et al., 2011).

У цьому плані цікавими були б дослідження стосовно композитної дії нанокобальту та пробіотика в годівлі птиці.

Мета роботи - визначити вплив наночасток Кобальту та пробіотика на основі асоціації мікроорганізмів роду Lactobacillus на деякі показники імунної системи, обміну білків та гемопоезу у птиці.

\section{Матеріал і методи досліджень}

В якості біологічного об'єкта використовували 50 курей промислового поголів'я кросу Хайсекс браун м'ясо-яєчного напряму продуктивності, віком 400 діб, масою 1400-1700 г.

У роботі використовували дослідний зразок наночасток Кобальту (НчСо), вихідна концентрація 2056,0 мкг/ $\mathrm{cm}^{3}$ за металом, середнього розміру ( 100,0 $\pm 10,0)$ нм). Наночастки Кобальту синтезували шляхом відновлення кобальту хлориду $\left(\mathrm{CoCl}_{2}\right)$ за взаємодії з натрію борогідридом. Як стабілізатор використовували розчин декстрину (30000 - 40000 Да) у 0,9\% фізіологічному розчині натрію хлориду.

У роботі використовували дослідний зразок пробіотику на основі асоціації мікроорганізмів роду Lactobacillus.

Птицю перед дослідом за принципом аналогів розподілили на п’ять груп по 10 у кожній і 10 діб витримували у адаптаційному період.

Кури контрольної групи отримували повнораціонний комбікорм згідно з нормами для курей яєчного напрямку відповідно до рекомендацій (Svezhencov et 
al., 2006), у якості питної води використовували водопровідну воду без добавок. Кури I-IV дослідних груп отримували 3 водою Пробіотик у відповідності 3 рекомендаціями до застосування $\left(1,0 \mathrm{~cm}^{3} /\right.$ дм$\left.^{3}\right)$. Кури IIIV дослідних груп додатково отримували добавки до комбікорму: курям II дослідної групи до комбікорму додавали кобальту хлорид у дозі 0,08 мг/кг маси тіла (1,0 мг/кг корму) (в перерахунку на метал), курям III дослідної групи у комбікорм вводили наночастки Кобальту (НчСо) у дозі 0,08 мг/кг маси тіла (1,0 мг/кг корму) i птиці IV групи до комбікорму додавали НчСо у дозі 0,8 мг/кг маси тіла (10,0 мг/кг корму). Препарати змішували з $200 \mathrm{~cm}^{3}$ водопровідної води та вносили в корм безпосередньо перед згодовуванням. Птиця мала вільний доступ до води та корму.

Упродовж проведення досліду за птицею вели спостереження. До задавання препаратів (n=5) по одній птиці з кожної групи, через 14, 28 діб після початку та через 14 діб після закінчення задавання препаратів $(\mathrm{n}=3)$ проводили декапітацію птиці після попереднього інгаляційного хлороформного наркозу та шляхом тотального знекровлення відбирали проби крові для гематологічних, біохімічних та імунологічних досліджень.

Термін дослідження - 42 доби.

Під час проведення експерименту визначали:

1. рівень загального гемоглобіну за гемоглобінціанідним методом 3 ацетонціангідрином, кількість еритроцитів за спектрофотометричним методом 3 2,8\% розчином натрію хлориду та лейкоцитів - шляхом підрахунку в камері Горяєва;

2. рівень загального білка та його фракцій електрофоретично;

3. концентрацію циркулюючих імунних комплексів середньої молекулярної маси (ЦІК) за методом Гриневича Ю. А. шляхом осадження білкових комплексів антиген-антитіло ПЕГ-6000;

4. рівень серомукоїдів $(\mathrm{Sm})$ за різницею оптичної густини при довжині хвиль 260 нм та 280 нм, як описано в роботі Меньшикова В. B. (Vlizlo et al., 2012).

Результати досліджень виражали відповідно до Міжнародної системи одиниць, рекомендованої для використання у клінічній та лабораторній практиці і обробляли статистично з використанням пакету програм Microsoft Excel 2003 (for Windows XР), вірогідність отриманих результатів оцінювали за критерієм Ст'юдента.

\section{Результати та їх обговорення}

3 метою визначення біосумісності дослідного зразка пробіотику та наночасток Кобальту (НчСо) в порівнянні з розчином кобальту хлориду $\left(\mathrm{CoCl}_{2}\right)$ за умов хронічного аліментарного надходження до організму дослідних курей-несучок проводили дослідження клініко-біохімічних показників в динаміці 42 діб.

У таблиці 1 наведені результати досліджень гематологічних показників у експериментальних курей у динаміці задавання препаратів. Так, у крові курей I дослідної групи, які одержували лише пробіотик, впродовж експерименту не реєстрували вірогідних змін вмісту еритроцитів і лейкоцитів, але визначали поступове підвищення рівня загального гемоглобіну впродовж задавання препарату у середньому на 7,8 i $18,5 \%(\mathrm{p} \leq 0,05)$ відносно контрольних значень. Через 14 діб після припинення задавання пробіотику значення загального гемоглобіну починали знижуватись, але були вищими за контрольні в середньому на $14,0 \%(\mathrm{p} \leq 0,05)$.

Вміст еритроцитів, лейкоцитів та загального гемоглобіну в крові курей-несучок за умов впливу добавок Кобальту та пробіотику у динаміці 42 діб $(\mathrm{M} \pm \mathrm{m} ; \mathrm{n}=3)$

\begin{tabular}{|c|c|c|c|c|}
\hline \multirow[t]{2}{*}{ Група тварин } & \multicolumn{4}{|c|}{ Термін дослідження } \\
\hline & I & II & III & IV \\
\hline \multicolumn{5}{|c|}{ Еритроцити, $10^{12} /$ дм $^{3}$} \\
\hline Контроль & \multirow[t]{5}{*}{$4,08 \pm 0,14$} & $4,05 \pm 0,10$ & $3,86 \pm 0,26$ & $3,90 \pm 0,16$ \\
\hline I дослід & & $4,14 \pm 0,12$ & $3,92 \pm 0,05$ & $4,08 \pm 0,12$ \\
\hline II дослід & & $3,80 \pm 0,11$ & $3,72 \pm 0,13$ & $4,10 \pm 0,13$ \\
\hline III дослід & & $4,46 \pm 0,08^{*}$ & $4,54 \pm 0,15^{*}$ & $4,47 \pm 0,04^{*}$ \\
\hline IV дослід & & $3,75 \pm 0,06$ & $3,80 \pm 0,17$ & $3,86 \pm 0,11$ \\
\hline \multicolumn{5}{|c|}{ Лейкоцити, $10^{9} /$ дм $^{3}$} \\
\hline Контроль & \multirow[t]{5}{*}{$21,38 \pm 1,05$} & $22,06 \pm 2,02$ & $21,25 \pm 3,42$ & $24,05 \pm 3,48$ \\
\hline I дослід & & $19,94 \pm 2,81$ & $20,20 \pm 1,55$ & $20,70 \pm 2,02$ \\
\hline II дослід & & $20,23 \pm 1,82$ & $21,62 \pm 1,18$ & $23,22 \pm 1,68$ \\
\hline III дослід & & $21,28 \pm 1,25$ & $19,15 \pm 3,00$ & $20,72 \pm 3,06$ \\
\hline IV дослід & & $21,50 \pm 1,84$ & $22,03 \pm 3,02$ & $21,80 \pm 2,22$ \\
\hline \multicolumn{5}{|c|}{ Загальний $\mathrm{Hb}$, г/дм ${ }^{3}$} \\
\hline Контроль & \multirow[t]{5}{*}{$91,32 \pm 4,25$} & $92,09 \pm 5,30$ & $91,52 \pm 4,41$ & $88,68 \pm 6,22$ \\
\hline I дослід & & $99,24 \pm 3,61$ & $108,48 \pm 3,25^{*}$ & $101,10 \pm 5,10^{*}$ \\
\hline II дослід & & $90,31 \pm 4,50$ & $91,76 \pm 5,27$ & $93,02 \pm 7,02$ \\
\hline III дослід & & $111,88 \pm 4,72^{*}$ & $112,50 \pm 4,00 *$ & $106,22 \pm 6,05$ \\
\hline IV дослід & & $81,25 \pm 6,44$ & $98,50 \pm 5,12$ & $90,80 \pm 3,16$ \\
\hline
\end{tabular}

Примітка: * - різниця значень вірогідна при $(\mathrm{p} \leq 0,05)$ відносно значень такого показника у контрольних тварин у відповідний термін дослідження 
Кількість еритроцитів, лейкоцитів і загального гемоглобіну в крові курей II дослідної групи, які одержували добавки пробіотику та кобальту хлориду, впродовж експерименту не набувала за значеннями вірогідних відхилень від такої у групі контролю.

Встановлено, що задавання Кобальту у нанодисперсній формі на фоні пробіотику впливало на характер змін гематологічних показників курей. Так, у крові курей, які одержували НчСо у меншій дозі (0,08 мг/кг маси тіла, III дослід), на усіх термінах досліджень визначали вірогідне зростання рівня еритроцитів, що корелювало 3 підвищенням вмісту загального гемоглобіну відносно їх значень у контролі.

Так, вже через 14 діб від початку задавання препаратів у крові птиці цієї групи відсоток зростання еритроцитів і загального гемоглобіну складав у середньому $10,1 \%$ і $21,5 \%(\mathrm{p} \leq 0,05)$ відносно контрольних значень.

У крові курей, що одержували НчСо у більшій дозі (0,80 мг/кг маси тіла, IV дослід), навпаки, встановлювали тенденцію до зниження кількості еритроцитів і загального гемоглобіну через 14 діб після початку задавання, що дорівнювало у середньому 7,4\% і 11,8\% $(\mathrm{p} \leq 0,05)$. У подальші терміни досліджень рівень цих показників не набував статистичних відхилень від контрольного.
Слід відзначити, що вміст лейкоцитів у крові птиці усіх дослідних груп впродовж всього експерименту коливався у межах їх контрольних значень.

Здатність організму протистояти агресивному впливу чинників біотичної і абіотичної природи (екзо- і ендотоксинів) тісно пов'язана 3 реактивністю організму, являючи собою одне з основних іiі наслідків і виразів. Неспецифічна резистентність залежить від стану бар'єрних систем (шкіри, слизових оболонок, системи мононуклеарних фагоцитів та ін.), від неспецифічних факторів крові і тканин, реакцій нервової системи та системи гіпофіз - кора наднирників. Значне підвищення як неспецифічної, так і специфічної резистентності може бути досягнуте за допомогою адаптації до різних факторів впливу.

У таблиці 2 наведені результати досліджень показників білкового профілю та стану неспецифічної резистентності у плазмі крові експериментальної птиці, що одержували на фоні пробіотику добавки Кобальту у різних дисперсних формах у динаміці експерименту.

Із результатів досліджень виявляється, що перебудови у протеїнограмі крові визначали лише в курей, які одержували саме пробіотик (I дослід) і пробіотик разом із НчСо в обох дозах (III і IV досліди), але вони були різноспрямовані.

Таблиия 2

Стан показників білкового профілю та неспецифічної резистентності у плазмі крові курей-несучок за умов впливу добавок Кобальту та пробіотику у динаміці 42 діб $(\mathrm{M} \pm \mathbf{m} ; \mathrm{n}=3)$

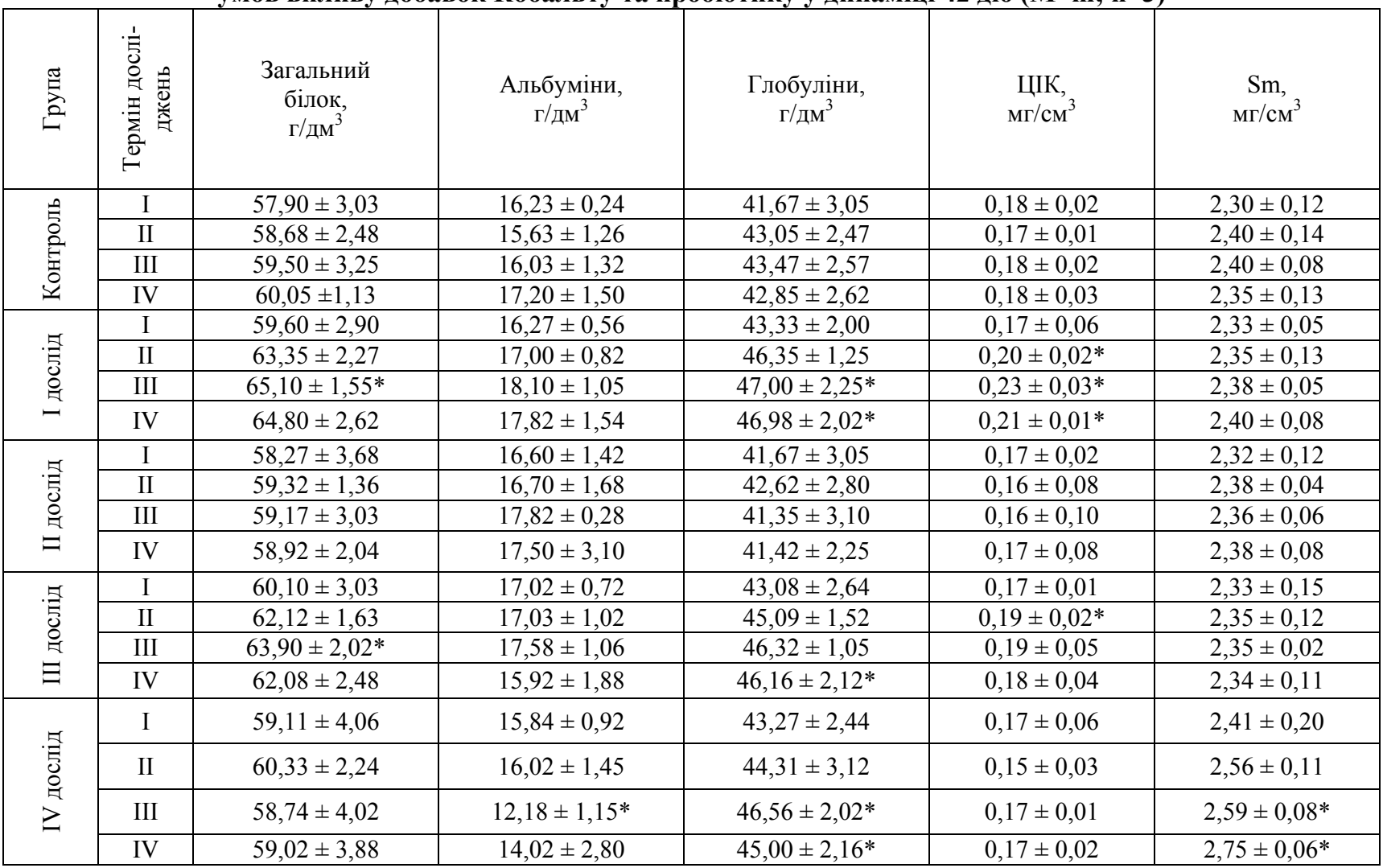

Так, у плазмі крові курей I і ІІІ дослідних груп під впливом добавок підвищувався рівень загального білку, починаючи 3 14-ої доби після початку задавання, що в середньому складало 8,4\% і 6,7\% відпові- дно відносно контрольних значень цього показника. Причому така тенденція зберігалась й для курей, які одержували пробіотик, наприкінці досліду - через 14 діб після припинення задавання препарату. 
Підвищення рівня загальних протеїнів у плазмі крові курей I і III дослідних груп супроводжується зі зростанням загальної кількості глобулінів на фоні зберігання значень альбумінів на контрольному (фізіологічному) рівні. Так, найвищий відсоток збільшення вмісту загальних глобулінів для курей I і III дослідних груп складав у середньому 9,6\% (p $\leq 0,05)$ i 7,7\% відповідно.

У крові курей, які одержували впродовж 28 діб пробіотик з добавкою нанокобальту в вищій дозі (IV дослід), на фоні нормального рівня загального білка встановлювали кількісне перерозподілення альбумінової та глобулінових фракцій. А саме - починаючи 3 28-ої доби після початку і на 14-ту добу включно після припинення задавання препаратів уміст альбумінів знижувався, а загальних глобулінів зростав, у середньому на $16,3 \%(\mathrm{p} \leq 0,05)$ та $6,1 \%$ відносно їх контрольного рівня.

Саме на дані терміни досліджень встановлювали у плазмі крові курей IV дослідної групи вірогідне зростання рівня серомукоїдів, які належать до $\alpha-$ фетопротеїнів - білків - імуносупресорів, у середньому на $10,5 \%$, за рахунок чого, очевидно, відбувалось зареєстроване збільшення фракції загальних глобулінів.

Слід зазначити, що зафіксоване збільшення рівня загальних глобулінів внаслідок 28-добового потрапляння саме пробіотику та пробіотику разом з НчСо (I i III досліди) перебувало у фізіологічних межах даного показника та корелювало 3 підвищенням утворення ЦІК середньої молекулярної маси $(\mathrm{p} \leq 0,05)$, що $є$ ознаками індукції гуморального імунітету та посилення імунної реактивності в організмі дослідної птиці.

\section{Висновки}

Одержані результати, у сукупності з даними динаміки кількості еритроцитів і загального гемоглобіну, змінами у протеїнограмі переконливо свідчать про адаптогенний вплив пробіотику та НчСо у дозі 0,08 мг/кг маси тіла (III дослід) на стан неспецифічної резистентності та білкового обміну в організмі дослідної птиці.

Але аліментарне хронічне потрапляння пробіотику разом з НчСо у дозі 0,80 мг/кг маси тіла (IV дослід) на пізніх строках досліджень призводило до таких змін у протеїнограмі, що $є$ характерними ознаками порушення білоксинтетичної функції печінки (за гіпоальбумінемією) та розвитку імуносупресії (за підвищенням рівня серомукоїдів).

За підсумком результатів хронічного токсикологічного експерименту на курях-несучках можна стверджувати про нешкідливість дії саме пробіотику та пробіотику разом із добавкою Кобальту у вигляді солі та наночасток у дозі 0,08 мг/кг маси тіла, що дозволяє вважати ії дійсно як біотичну.

Адаптогенний ефект препаратів пробіотику та добавки НчСо у дозі 0,08 мг/кг маси тіла при аліментарному надходженні до організму курей полягає у поси- ленні імунних реакцій поряд з відновленням показників еритропоезу та білкового обміну.

Перспективи подальших досліджень. Для визначення мікробіологічних основ дії НчСо та пробіотика, наступним етапом буде вивчення особливостей біоплівкоутворюючої здатності мікроорганізмів кишечника птиці.

\section{Бібліографічні посилання}

Cvilihovs'kyj, M.I., Bereza, V.I., Dul'njev, P.G., Grushans'ka, N.G., Jakymchuk, O.M. (2010). Veterynarna nanomedycyna: perspektyvy zastosuvannja u diagnostyci i profilaktyci hvorob ta likuvanni tvaryn. Naukovyj visnyk L'vivs'kogo nacional'nogo universytetu veterynarnoi' medycyny ta biotehnologij im. S.Z. Gzhyc'kogo. 12, №3(45), 296299 (in Ukrainian).

Skyba O.O., Golopura S.I., Grushans'ka N.G., Cvilihovs'kyj M.I. (2009). Vplyv preparatu "Stymtel» na pokaznyky aktyvnosti transaminaz krovi suhostijnyh koriv. Naukovyj visnyk L'vivs'kogo nacional'nogo universytetu veterynarnoi' medycyny ta biotehnologij imeni S.Z. Gzhyc'kogo. 11, №3(42), 140-144 (in Ukrainian).

Jefanov, V.S. (2011). Na shljahu do innovacijnyh likars'kyh preparativ. Informacija. 4, 49-50 (in Ukrainian).

Jakymchuk, O.M., Bereza, V.I., Grushans'ka, N.G., Cvilihovs'kyj, M.I. (2009). Imunobiologichna reaktyvnist' organizmu porosnyh svynomatok pid chas zastosuvannja mineral'nogo preparatu Suimin-P. Visnyk Bilocerkivs'kogo derzhavnogo agrarnogo universytetu. 60, 2, 149-152 (in Ukrainian).

Vlizlo, V.V., Fedoruk, R.S., Ratych, I.B. ta in. (2012). Laboratorni metody doslidzhen' u biologii', tvarynnyctvi ta veterynarnij medycyni: dovidnyk. L'viv, SPOLOM (in Ukrainian).

Polishhuk, A.A., Bulavkina, T.P. (2010). Suchasni kormovi dobavky $\mathrm{v}$ godivli tvaryn ta ptyci. Visnyk Poltavs'koi' derzhavnoi' agrarnoi' akademii'. 2, 63-66 (in Ukrainian).

Bereza, V.I., Grushans'ka, N.G., Cvilihovs'kyj, M.I. (2010). Porushen' obminu rechovyn u laktujuchyh svynomatok v gospodarstvah central'noi' biogeohimichnoi' zony Ukrai'ny. Problemy zooinzhenerii' ta veterynarnoi' medycyny: Zbirnyk naukovyh prac' 21, 2, 103-107 (in Ukrainian).

Besulin, V.I., Gordijenko, V.M., Merkulova, I.V. (2011). Rezul'taty vykorystannja probiotyku protekto-aktyv pid chas godivli perepeliv v umovah riznyh tehnologij. Suchasni problemy v godivli sil's'kogospodars'kyh tvaryn. №8(48), 48-55 (in Ukrainian).

Svezhencov, A.N., Uzdrik, R.M., Egorov I.A. (2006). Korma i kormlenie s/h pticy. Dnepropetr. agrar. un-t. gruppa kompanii „Edinstvo”, Vseross. nauch.-issled. i tehnol. in-t pticevodstva. Dnepropetrovsk: ARTPRESS (in Ukrainian).

Стаття надійшла до редакиї 8.10.2016 